\title{
ARTICLE
}

\section{OLIGOPOLY COORDINATION, ECONOMIC ANALYSIS, AND THE PROPHYLACTIC ROLE OF HORIZONTAL MERGER ENFORCEMENT}

\author{
JONATHAN B. BAKER ${ }^{\dagger} \&$ JOSEPH FARRELL ${ }^{\dagger}$
}

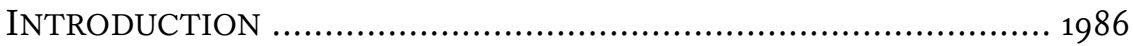

I. THE PRoblem of CoORdinAtED Oligopoly CONDUCT.......... 1991

A. Empirical, Experimental, and Real-World Evidence .......................1992

B. Economic Theory ................................................................1996

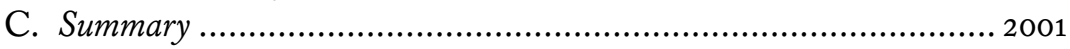

II. The Dubious ARGUMENT FOR SKEPTICISM ABOUT

OLIGOPOLY COORDINATION ......................................... 2002

III. IMPLICATIONS FOR ANTITRUST MERGER ENFORCEMENT..... 2007

A. Coordinated Effects Involving Purposive Strategic Conduct .............. 2009

B. Coordinated Effects Involving Nonpurposive Strategic Conduct ......... 2012

1. Reinforcing Reactions .................................................... 2013

2. Diluting Reactions ........................................................ 2014

3. Concluding Comments on the Coordinated Effects of

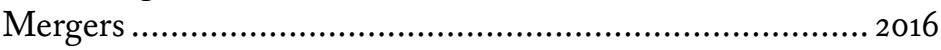

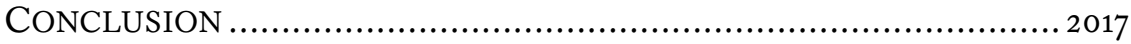

† Research Professor of Law, American University Washington College of Law.

† Professor of Economics, University of California, Berkeley. The authors are grateful to Cory Capps, Joe Harrington, Alex MacKay, Nate Miller, Steve Salop, Katja Seim, and to participants in the American University Washington College of Law Business Law Faculty Workshop and the University of Pennsylvania Law Review Antitrust Symposium. 


\section{INTRODUCTION}

For decades, the major United States airlines have raised passenger fares through coordinated fare-setting when their route networks overlap, according to the United States Department of Justice. Through its review of company documents and testimony, the Justice Department found that when major airlines have overlapping route networks, they respond to rivals' price changes across multiple routes and thereby discourage competition from their rivals. ${ }^{1} \mathrm{~A}$ recent empirical study reached a similar conclusion: It found that fares have increased for this reason on more than 1000 routes nationwide and even that American and Delta, two airlines with substantial route overlaps, have come close to cooperating perfectly on routes they both serve. ${ }^{2}$

Airlines are not the only major industry in which the major firms reach coordinated outcomes in oligopoly markets (that is, markets in which a small number of firms are significant rivals), leading to higher prices and other harms to buyers. ${ }^{3}$ A recent empirical study found that the 2008 joint venture between Miller and Coors allowed the major brewers to coordinate to reduce competition between themselves, thereby increasing the price of beer by an

1 In the early 1990s, the government found that when a rival reduced fares, an airline would commonly price match on that route and also on another route that was a more important route to the airline that cut fares (for example, a route with an end point at the discounter's hub). Proposed Final Judgment and Competitive Impact Statement, United States v. Airline Tariff Publ'g Co., 59 Fed. Reg. 15,225, 15,225 (Mar. 31, 1994); Proposed Final Judgment and Competitive Impact Statement, United States v. Airline Tariff Publ'g Co., $5^{8}$ Fed. Reg. 3,971, 3,971 (Jan. 12, 1993). The Justice Department more recently alleged that the airlines continue to employ such "cross-market initiatives" to deter discounting and prevent fare wars. See Amended Complaint at 16, United States v. U.S. Airways Grp., Inc., 38 F. Supp. 3d 69 (D.D.C. Sept. 5, 2013) (No. 1:13-cv-01236-CKK). Multimarket contact is not the only coordination mechanism that the airlines employ. See, e.g., Gaurab Aryal, Federico Ciliberto \& Benjamin T. Leyden, Coordinated Capacity Reductions and Public Communication in the Airline Industry 2 (Becker Friedman Inst., Working Paper No. 2018-11, 2020) (finding evidence suggesting that legacy airlines use public communication in quarterly earnings calls to coordinate on capacity levels).

2 Federico Ciliberto \& Jonathan W. Williams, Does Multimarket Contact Facilitate Tacit Collusion? Inference on Conduct Parameters in the Airline Industry, 45 RAND J. ECON. 764, 765, 789 (2014) (analyzing data from 2007); see also William N. Evans \& Ioannis N. Kessides, Living by the "Golden Rule": Multimarket Contact in the U.S. Airline Industry, 109 Q.J. ECON. 341, 341-43 (1994) (finding a relationship between greater multimarket contact and higher airline fares using data from the mid-1980s). Enhanced coordination arising from a substantial increase in multimarket contact would be expected to raise airfares by two to five percent on routes where such contact is already at a moderate level. Ciliberto \& Williams, supra, at 85-86.

3 For other empirical examples, see infra notes 23-25 and accompanying text. Our Article focuses on coordination among sellers and does not discuss coordination among buyers, although many of the issues are parallel. 
estimated six to eight percent. ${ }^{4}$ They plausibly achieved the higher prices through leader-follower pricing. ${ }^{5}$

One possible interpretation of the price increase is that the airlines and brewers engaged in explicit price-fixing or market division-collusive conduct that would violate Section 1 of the Sherman Act and would likely be criminally prosecuted by the Department of Justice if uncovered. That possibility would suggest that express cartels - those operating under explicit agreements-often go undetected and undeterred, consistent with what empirical studies have found. ${ }^{6}$ Another interpretation of such evidence, which is also plausible and, we suspect, more likely, is that oligopoly conduct can often lead to coordinated outcomes that restrict competition without firms expressly colluding on an agreement that would violate Section 1 of the Sherman Act. 7 They might achieve those coordinated outcomes purposively, by identifying consensus terms of coordination and deterring cheating, or arrive at those outcomes simply as a consequence of recognizing their

4 Nathan H. Miller \& Matthew C. Weinberg, Understanding the Price Effects of the MillerCoors Joint Venture, 85 ECONOMETRICA 1763, 1763 (2017). These price increases are over-and-above price changes that would have come about were the firms not coordinating, in the sense of how we use the term in this Article.

5 See Nathan H. Miller, Gloria Sheu \& Matthew C. Weinberg, Oligopolistic Price Leadership and Mergers: The United States Beer Industry 2-4 (June 14, 2019) (unpublished manuscript), https://www.ftc.gov/system/files/documents/public_events/1494697/weinbergmillersheu.pdf [https://perma.cc/5MTQ-UHNN] (showing that price leadership could lead to higher prices in this industry and referencing Justice Department pleadings describing the largest brewer as a price leader).

6 Joseph E. Harrington, Jr. \& Yanhao Wei, What Can the Duration of Discovered Cartels Tell Us About the Duration of All Cartels? 127 ECON. J. 1977, 1978 (2017) (finding that a cartel has a seventeen percent chance annually of either collapsing or being discovered); Peter G. Bryant \& E. Woodrow Eckard, Price Fixing: The Probability of Getting Caught, 73 REV. ECON. \& STAT. 531, 535 (1991) (concluding that the Justice Department detects at most thirteen to seventeen percent of cartels annually). By one back-of-the envelope calculation, nearly twenty-nine express cartels are active in the United States at any one time, overcharging U.S. buyers by $\$ 8.7$ billion annually. JONATHAN B. BAKER, THE ANTITRUST PARADIGM: RESTORING A COMPETITIVE ECONOMY 14 (2019).

7 Coordinated outcomes that did not arise from express collusion can occasionally be addressed under Section 1 of the Sherman Act by challenging practices facilitating coordination that have been adopted by agreement among rivals. E.g., United States v. Container Corp., 393 U.S. 333, 336-38 (1969) (finding that price verification on demand stabilized prices); see also id. at 339-40 (Fortas, J., concurring) (concluding that the information exchange limited price competition); $c f$. United States v. Gen. Elec. Co. and Westinghouse Elec. Co., No. 28228, 1977 WL 1474, at *1 (E.D. Pa. Sept. 16, 1977) (modifying consent decree to prevent firms previously convicted of price-fixing from adopting various practices); Proposed Modification of Existing Judgments, United States v. Gen. Elec. Co., 42 Fed. Reg. 17,004, 17,004 (Mar. 30, 1977) (describing practices electrical equipment firms used to raise prices without express negotiation, including standardized product definitions, published price books, and buyer protection policies (such as meeting competition and most-favored-nation clauses)). One of us has argued that the Federal Trade Commission should use competition rulemaking to prohibit practices facilitating oligopoly coordination, including practices unilaterally adopted. See Jonathan B. Baker, Two Sherman Act Section 1 Dilemmas: Parallel Pricing, the Oligopoly Problem, and Contemporary Economic Theory, 38 ANTITRUST BULL. 143, 207-19 (1993). 
interdependence and anticipating the natural and predictable reactions of their rivals to their price changes.

Whether arrived at purposively or not, these examples of coordinated conduct suggest that the possibility of coordination among oligopolists is not effectively prevented by the prospect of Sherman Act liability. ${ }^{8}$ This theme contrasts with suggestions by antitrust commentators and courts influenced by the Chicago school: that oligopolies usually perform competitively absent express collusion, and that express collusion itself is difficult and therefore rare. ${ }^{9}$ As we describe below, the economics literature does not support those Chicago claims.

In brief summary of economic concepts that we will explain more fully below, ${ }^{10}$ we define coordinated oligopoly outcomes as price elevation ${ }^{11}$ arising from strategic conduct. We say that a firm acts strategically when in setting prices, the firm takes into account how it expects that its rivals will respondas one would expect firms to do when those responses would be strong and likely to matter to buyers. ${ }^{12}$ In short, when high prices persist because firms are discouraged from cutting price by the anticipated responses of their rivals, we term the outcome coordinated.13

We term the outcome coordinated regardless of how those anticipated responses arise. ${ }^{14}$ Our point is the breadth of this category, not the creation

8 The most influential antitrust treatise of the mid-twentieth century took a similar view. CARL KAYSEN \& DONALD F. TURNER, ANTITRUST POLICY: AN ECONOMIC AND LEGAL ANALYSIS 110 (1959) (suggesting that the joint exercise of market power, exercised without engaging in conduct violating the Sherman Act, characterizes "a considerable number" of markets).

9 See infra Part II.

10 See infra Section I.B.

11 Alterations to nonprice terms of competition that harm buyers would be treated analogously. We focus on price for concreteness.

12 When both anticipated rival responses ("conjectural variations" in economic language) and buyer reactions ("diversion ratios" in economic language) are substantial, these factors will substantially affect the firm's gain or loss of customers in response to its cutting or raising its price and therefore its incentive to do so. For textbook discussions of the determination of equilibrium prices in oligopoly when firms have nonzero conjectural variations, see STEPHEN MARTIN, INDUSTRIAL ORGANIZATION IN CONTEXT 75 (2010); F.M. SCHERER \& DAVID ROSS, INDUSTRIAL MARKET STRUCTURE AND ECONOMIC PERFORMANCE 206-08 (3d ed. 1990).

13 The noncoordinated benchmark for price is thus the price that would arise if firms behaved nonstrategically, that is, in a static Nash equilibrium when firms choose price or output, a widely used framework for antitrust and economic analysis. That framework is often in practice identified with "unilateral" oligopoly conduct, which in turn is commonly taken to be distinct from "coordinated" conduct. See U.S. DEP'T OF JUSTICE \& FED. TRADE COMM'N, HorizOnTAL MERGER GUIDELINES (2010) 20-27, https://www.justice.gov/sites/default/files/atr/legacy/ 2010/08/19/hmg-2010.pdf [https://perma.cc/4 $\mathrm{V}_{2} \mathrm{~K}-\mathrm{D}_{3} \mathrm{CN}$ ] [hereinafter $2010 \mathrm{HMG]} \mathrm{(discussing}$ unilateral and coordinated effects separately).

14 Our definition is consistent with the way coordination is described in the horizontal merger guidelines. The 2010 Guidelines state: "Coordinated interaction involves conduct by multiple firms that is profitable for each of them only as a result of the accommodating reactions of the others." Id. 
of new dichotomies, but we nevertheless distinguish two types of responses. When firms act on the expectation that rivals will punish cheating on a common understanding in order to sustain and implement that understanding, we call the strategic conduct "purposive." 15 In other cases, the strategic conduct is "nonpurposive." We use the latter term when firms respond to one another's price changes in a natural and predictable business way, rather than as a part of a scheme or attempt to develop a consensus or deter price-cutting. As Donald Turner explained nearly six decades ago, a rational oligopolist understands that its rivals will "inevitably react" when it cuts prices "because otherwise the price cut will make a substantial inroad on their sales." 16 That rivals will "inevitably react" can lead to coordinated outcomes even when firms do not seek to develop a common understanding or punish cheating. We view the distinction between purposive and nonpurposive conduct as suggestive and useful, but not as setting forth an

at 24. Similarly, the 1992 Guidelines state: "Coordinated interaction is comprised of actions by a group of firms that are profitable for each of them only as a result of the accommodating reactions of the others." U.S. DEP'T OF JUSTICE \& FED. TRAde COMm'N, Horizontal Merger GUIDELINES 17 (1992) https://www.justice.gov/sites/default/files/atr/legacy/2007/o7/11/11250.pdf [https://perma.cc/3XYF-6Y69] [hereinafter 1992 HMG].

15 We use the term "purposive" to convey an important distinction both among forms of conduct and among ways of analyzing conduct, but we do not mean to suggest all possible connotations of the term. We do not intend the term to be interpreted to incorporate all conduct undertaken in anticipation of likely responses. For instance, if (as in economists' Stackelberg equilibrium) a price leader commits to its price and others set their prices to maximize their profits in reliance on that commitment, we would call the leader's strategic conduct nonpurposive. But if the followers always match the leader's price even when that is not their best response based on costs and demand, because they expect the leader to punish them if they do otherwise, we would call the leader's conduct purposive. Purposive strategic conduct is closer to "negotiating" or "scheming" or "rewarding and punishing" than to naturally "reacting." The distinction is also analogous to the distinction Thomas Schelling makes between a "warning" and a "threat." Both are communications aimed at shaping the responses of others (which could be other nations, in international affairs). A warning describes what would already (absent the communication) be the actor's true and inherent interest (akin to a natural and predictable, or nonpurposive, response), while a threat communicates a calculated commitment to a position not otherwise in the actor's interest (akin to conduct that would be purposive if carried out). THOMAS C. SCHELling, THE STRATEGY OF CONFLICT 12324 (1960). The term "purposive" may also mislead to the extent it suggests that the distinction turns on the subjective intent of the decisionmakers at the firms. Intent evidence may aid in understanding and interpreting conduct, however. See infra text accompanying notes 66-69 (providing hypothetical examples of documentary or testimonial evidence relevant to classifying strategic conduct as purposive or nonpurposive).

16 Donald F. Turner, The Definition of Agreement Under the Sherman Act: Conscious Parallelism and Refusals to Deal, 75 HARV. L. REV. 655, 665 (1962). If, for example, Turner explains, "there are only three producers of equal size and a price cut by one doubles his sales, the sales of each of his two competitors will be cut in half." Id. 
analytically watertight classification scheme. ${ }^{17}$ Indeed, these two forms of strategic conduct can coexist, ${ }^{18}$ and there undoubtedly are gray areas.

The previously referenced studies of airlines and brewing found that firms reached coordinated outcomes but did not seek to distinguish between purposive and nonpurposive conduct. Either type of strategic conduct could result in price leadership (brewing) or be facilitated by greater multimarket contact (airlines). ${ }^{19}$ It is nonetheless important for antitrust enforcement to be alert for risks both of purposive and of nonpurposive strategic conduct. Because so much recent antitrust discussion has focused on coordinated outcomes arising from purposive conduct, distinguishing between the two forms-even while recognizing that some strategic conduct is hard to classify-is helpful in drawing proper attention to nonpurposive coordination, and, relatedly, in understanding why antitrust commentators and courts influenced by the Chicago school wrongly dismiss the latter possibility. Distinguishing the two types of strategic conduct also facilitates a detailed economic analysis of the competitive effects of firm conduct, as we illustrate below with respect to evaluating the coordinated effects of horizontal mergers.

As has long been recognized, the difficulty of attacking express cartels and the Sherman Act's circumscribed coverage of other forms of coordination 20 gives horizontal merger enforcement an important prophylactic role: it increases the importance of preventing changes in market structure through

17 To illustrate the distinctions our framework makes using categories and concepts taken from economic theory, suppose price is the decision variable. If the oligopolists adopt Bertrand-Nash responses (conjectures of zero) in a one-time interaction, the outcome is our noncoordination benchmark. If the firms have continuous and nonzero conjectures that are not history-dependent, and prices exceed benchmark levels, the outcome is coordinated and we would likely say achieved through nonpurposive strategic behavior. If the firms' strategies are discontinuous and history-dependent, as with punishment responses, the outcome is coordinated and achieved through purposive conduct. In particular we would apply that label to express collusion (for example, an express agreement to raise price or allocate markets or customers), which often involves such punishment responses.

18 See MiCHAEL D. WHINSTON, LECTURES ON ANTITRUST ECONOMICS 41 (2006) (indicating that a factor that makes coordination easier is likely to do so both when firms talk and when they do not). More generally, purposive and nonpurposive coordinated conduct will coexist when an oligopoly supergame model leads to elevated prices while supposing that the oligopolists revert to an outcome consistent with some nonpurposive coordination (an outcome that falls short of joint profitmaximization) in the event the coordinated outcome from purposive conduct falls apart.

19 In discussing their results, though, the authors of these studies plausibly adopt purposive conduct interpretations. The authors of the brewing study take a modeling perspective that presumes purposive conduct. Miller, Sheu \& Weinberg, supra note 5 , at 2. The authors of the airlines study interpret increased multimarket conduct as loosening incentive compatibility constraints on coordinated outcomes, Ciliberto \& Williams, supra note 2, at 764, and discuss some of their results in terms of incentives to deviate from a coordinated outcome. Id. at $769,780$.

20 The Sherman Act has been interpreted to insulate many coordinated outcomes from antitrust liability. See, e.g., In re Text Messaging Antitrust Litig., 782 F.3d 867, 872 (7th Cir. 2015) ("Express collusion violates antitrust law; tacit collusion does not."). 
a horizontal merger that would make coordinated outcomes more likely or more effective. ${ }^{21}$ The Clayton Act focuses on whether a horizontal merger will harm competition, including by making coordination more likely or more effective, regardless of whether the coordination would independently violate the Sherman Act. For this reason, we look to merger enforcement when discussing the implications of our analysis for antitrust. 22

Although we explore a more detailed and nuanced economic analysis, one important conclusion is straightforward: whether through purposive or nonpurposive conduct, greater concentration can be expected to make coordination more likely, stronger, or more effective. Accordingly, our analysis supports a structural merger policy, by which mergers between rivals that increase concentration significantly in a concentrated market are presumed to harm competition.

In Part I of our Article, we explain why coordinated conduct is a serious concern. We explain in Part II why we disagree with the Chicago views that such conduct is unlikely absent express collusion and that express collusion itself is uncommon. Part III explains how our analysis of coordination should apply to merger enforcement.

\section{The PRoblem of COORDINATED Oligopoly CONDUCT}

Modern economics offers many reasons to think that coordinated outcomes may arise and persist in oligopoly markets. We begin with empirical, experimental, and real-world evidence, then review the relevant economic theory.

$21 \mathrm{See} 4$ Phillip E. AREedA \& HERBERT HovenKamp, ANTITRUST LAW: AN ANAlysis of ANTITRUST PRINCIPLES AND THEIR APPLICATION I 901(b)(2) (4th ed. 2016) (explaining that a "central objective of merger policy is to obstruct" the creation of "oligopolistic market structures in which tacit coordination can occur"); 6 PHILLIP E. AREEDA \& HERBERT HOVENKAMP, ANTITRUST LAW: AN ANALYSIS OF ANTITRUST PRINCIPLES AND THEIR APPLICATION ๆ 1432(d)(5) (3d ed. 2010) (describing the "containment" approach of addressing the oligopoly problem through prohibiting concentrating mergers and facilitating practices); see also Herbert Hovenkamp, Prophylactic Merger Policy, 70 HASTINGS L.J. 45, 51-55 (2018) (justifying an incipiency test under the Clayton Act based on the threat of post-merger coordination that would not violate the Sherman Act); $c f$. Richard A. Posner, Oligopoly and the Antitrust Laws: A Suggested Approach, 21 STAN. L. REV. 1562, 1566 (1969) (indicating that the "extraordinary stringency" of the merger guidelines that the Justice Department promulgated while Donald Turner was Assistant Attorney General "may reflect in part Turner's earlier expressed view that once a market has become highly concentrated there is little that can be done under existing law to prevent noncompetitive, interdependent pricing").

22 Our view of coordination is also relevant to a number of other important antitrust issues we do not discuss, including identifying express collusion, inferring collusive agreements from circumstantial evidence, and analyzing the horizontal consequences of vertical mergers. For analyses of economic issues raised by express collusion and its prosecution, see generally JOSEPH E. HARRINGTON, JR., THE THEORY OF COLLUSION AND COMPETITION POLICY (2017); ROBERT C. MARSHALL \& LESLIE M. MARX, THE ECONOMICS OF COLLUSION: CARTELS AND BIDDING RINGS (2012). 


\section{A. Empirical, Experimental, and Real-World Evidence}

The relevant empirical literature extends beyond the previously discussed studies of airlines and brewing. ${ }^{23}$ Studies have found that through strategic conduct leading to coordinated outcomes, prices of cellular telephone services increased between seven and ten percent; and prices for hospital services offered by multi-hospital systems increased between six and seven percent. ${ }^{24}$ In one urban retail gasoline market, dominant firms engaged in price leadership to establish, after many years of trying, coordinated prices as high as fifteen percent above those that would otherwise have prevailed without coordination. ${ }^{25}$

Empirical studies have also found that express cartels-one type of purposive coordination-are durable. According to one study, the average cartel lasted approximately eight years, even though many cartels in the sample were terminated by antitrust enforcement. ${ }^{26}$ Some cartels have survived more than forty years. ${ }^{27}$ These results indicate that coordinated outcomes, once attained, can readily be sustained.

Economists have identified a wide range of factors thought to facilitate coordination. One typical list includes: a small number of firms, simple or homogenous products, open and transparent transactions, excess capacity in the hands of rivals, predictable demand, small and frequent transactions, small buyers, inelastic market demand, low marginal costs relative to price, and high customer switching costs. ${ }^{28}$ The experimental economics literature

23 See Christopher John Sullivan, The Ice Cream Split: Empirically Distinguishing Price and Product Space Collusion, in Three Essays on Product Collusion 36, 65 (2017) (unpublished Ph.D. dissertation, University of Michigan), https://deepblue.lib.umich.edu/bitstream/handle/2027.42/ 138544/sullivcj_1.pdf?sequence=1\&isAllowed=y [https://perma.cc/VA2P-TYKM] (finding that through coordination over prices and product offerings of super-premium ice cream, Ben \& Jerry's and Häagen-Dazs raised average prices by nine and eleven percent, respectively).

24 Matt Schmitt, Multimarket Contact in the Hospital Industry, 10 AM. ECON. J.: ECON. POL'Y 361, 363 (2018); Meghan R. Busse, Multimarket Contact and Price Coordination in the Cellular Telephone Industry, 9 J. ECON. \& MGMT. STRATEGY 287, 317 (2000). For both industries, the studies found that coordinated outcomes were facilitated by multimarket conduct, as was found with airlines.

25 David P. Byrne \& Nicolas de Roos, Learning to Coordinate: A Study in Retail Gasoline, 109 AM. ECON. REV. 591, 600 (2019).

26 Margaret C. Levenstein \& Valerie Y. Suslow, Breaking Up Is Hard to Do: Determinants of Cartel Duration, 54 J.L. \& ECON. 455, 463 (2011); see also Ari Hyytinen, Frode Steen \& Otto Toivanen, Cartels Uncovered, 10 AM. ECON. J.: MiCROECONOMICS 190, 210 (2018) (finding that legal cartels in Finland had an average expected duration of 8.5 years); Harrington \& Wei, supra note 6, at 1998, 2002 (finding that cartels discovered by the Justice Department, and thus terminated by antitrust enforcement, had an average duration of 5.8 years; adjusted for a statistical bias, the estimated average duration is between 5.3 and 6.8 years).

27 Margaret C. Levenstein \& Valerie Y. Suslow, What Determines Cartel Success?, 44 J. ECON. LITERATURE 43, 53 tbl.2 (2006) (indicating that a number of cartels lasted at least forty years).

28 ANDREW I. GAVIL, WILLIAM E. KOVACIC, JONATHAN B. BAKER \& JOSHUA D. WRIGHT, Antitrust LaW in PERsPective: CASES, CONCEPTS AND PROBlems IN COMPETition POLICY 298-306 (3d ed. 2017) (setting forth factors facilitating or frustrating coordination and 
supports many of these predictions - and, in doing so, finds that coordinated outcomes are achieved and sustained in a range of laboratory settings, though they are missed or fall apart in others. ${ }^{29}$

Experimental studies have found occasional coordinated outcomes in "prisoners' dilemma" experiments when firms interact in a single period or for a fixed and certain number of periods. ${ }^{30}$ These are settings where economic models suggest that rational actors would do otherwise. The behavioral economics literature suggests that concerns for fairness and a desire for vengeance may support coordination by inducing firms to punish cheating even when that would not be a rational response. ${ }^{31} \mathrm{~A}$ recent experimental study lends some support. It finds that that coordination is more stable when firms target specific rivals for punishment rather than when they allow a coordinated consensus to break down, particularly when a large number of firms coordinate-that is to say, when the incentives of any

explaining their rationales). While lists of factors facilitating coordination like these have typically been created with purposive strategic conduct and the problem of inferring an agreement among rivals from circumstantial evidence in mind, the same factors would often also plausibly make nonpurposive coordination more of a threat.

29 See generally Wieland Müller \& Hans-Theo Normann, Experimental Economics in Antitrust, in 1 THE OXFORD HANDBOOK OF INTERNATIONAL ANTITRUST ECONOMICS 229, 230-37 (Roger D. Blair \& D. Daniel Sokol eds., 2014); Jan Potters \& Sigrid Suetens, Oligopoly Experiments in the Current Millennium, 27 J. ECON. SURVEYs 439, 448-50 (2013); Charles A. Holt, Industrial Organization: A Survey of Laboratory Research, in THE HANDBOOK OF EXPERIMENTAL ECONOMICS 349, 398-416 (John H. Kagel \& Alvin E. Roth eds., 1995).

30 Holt, supra note 29, at 402. In a prisoner's dilemma, a common, simple, and well-known way of modeling oligopoly interactions, all firms would profit if they can reach and sustain a coordinated outcome. But each firm would find it even more profitable to cheat on that outcome if they knew that their rivals would not respond. In a single-period interaction, or a repeated interaction over a known fixed period, standard theory would predict that the temptation to cheat prevents successful coordination. See id. at 399 (explaining how the prisoner's dilemma game models the possibility of coordinated outcomes); see also William J. Kolasky, Deputy Assistant Att'y Gen., Antitrust Div., U.S. Dep't of Justice, Coordinated Effects in Merger Review: From Dead Frenchmen to Beautiful Minds and Mavericks (April 24, 2002), http://www.usdoj.gov/atr/public/speeches/11050.htm [https://perma.cc/X783-UND4] (same).

31 Mark Armstrong \& Steffen Huck, Behavioral Economics and Antitrust, in 1 THE OXFORD HANDBOOK OF INTERNATIONAL ANTITRUST ECONOMICS 205, 212-13 (Roger D. Blair \& D. Daniel Sokol eds., 2014) (noting that "vengeance induces more aggressive punishments for deviating"). For game theoretic work on the possibility of collusion when firms predictably evade following through on threatened punishments that harm the punisher, see Joseph Farrell \& Eric Maskin, Renegotiation in Repeated Games, 1 GAMES \& ECON. BEHAV. 327, 328 (1989) (noting that instead of punishing the violator in ways that would hurt other participants, "it seems plausible that [firms] will renegotiate back to mutual cooperation”), B. Douglas Bernheim \& Debraj Ray, Collective Dynamic Consistency in Repeated Games, 1 GAMES \& ECON. BEHAV. 295, 296-97 (1989) (noting the possibility of firms renegotiating self-enforcing agreements), and Joseph Farrell, Renegotiation in Repeated Oligopoly Interaction, in INCENTIVES, ORGANIZATION, AND PUBliC ECONOMICS 303, 306 (Peter J. Hammond \& Gareth D. Myles eds., 200o) (noting that in less concentrated markets, "full collusion (or anything close to it) is inconsistent with what might seem a reasonable form of renegotiation-proofness"). 
individual firm to punish would be weak absent concerns for fairness. ${ }^{32}$ In addition, behavioral economists have raised the possibility that firms would choose not to cheat on a coordinated consensus even when it would appear rational do so if the coordinating firms can foster a sense of loyalty or esprit de corps among themselves. ${ }^{33}$

Real-world evidence similarly confirms the plausibility of coordinated oligopoly outcomes. Antitrust enforcers have found that express cartels with five or six (or even ten or more) members are not uncommon. ${ }^{34}$ Business schools routinely teach the adoption of practices that facilitate coordination without risking antitrust liability. 35

Coordination may not easily be recognized because coordinated outcomes in real-world markets, while harmful, do not necessarily approach the joint profitmaximizing outcome that a monopolist would achieve. Empirical studies and the case law show that coordination can be incomplete or imperfect in many ways, and that coordinated outcomes may be accompanied by conduct that is competitive in some respects. 36 This should not be surprising. Firms matching rivals' price-cuts is, from one perspective, quintessentially competitive behavior. But when firms anticipate that their rivals will behave that way-either in a natural business way or as a response to cheating-that expected reaction, which may seem competitive, can make coordinated outcomes possible by discouraging price-cutting in the first instance.

Even express cartels may not coordinate perfectly. The records of one express cartel, the early 2oth-century Sugar Institute, indicated that it would allow occasional cheating to go unpunished. 37 There are a number of other

32 Catherine Roux \& Christian Thöni, Collusion Among Many Firms: The Disciplinary Power of Targeted Punishment, 116 J. ECON. BEHAV. \& ORG. 83, 91 (2015). A number of prior experimental studies varying the number of market participants had found that tacit collusion was often unsuccessful outside of duopoly. Id. at 83-84.

33 Armstrong \& Huck, supra note 31 , at 214.

34 Kolasky, supra note 30; Margaret C. Levenstein \& Valerie Y. Suslow, What Determines Cartel Success?, 44 J. ECON. LiteraturE 43, 59 tbl.4 (2006); see also John William Hatfield, Scott Duke Kominers \& Richard Lowery, Collusion in Brokered Markets 3-4 (Harvard Bus. Sch., Working Paper No. 20-023, 2020), https://ssrn.com/abstract_id=3450767 [https://perma.cc/6 $\mathrm{PG}_{3}-\mathrm{JG}_{35}$ ] (explaining high real estate commission rates in markets with large numbers of independent brokers in terms of a supergame model of oligopoly conduct).

35 This has been common for at least four decades. Cf. MiChaEL E. Porter, COMPETitive STRATEGY: TECHNIQUES FOR ANALYZING INDUSTRIES AND COMPETITORS 92-95 (1980) (encouraging firms to seek to improve all firms' positions by employing active market signaling through announcements, selective advertising to discipline recalcitrant rivals, and price leadership); $i d$. at 106 (advocating standardization to simplify industry prices and other decision variables so that oligopolists can establish an advantageous focal point for their industry).

36 See infra notes 37-43 and accompanying text.

37 David Genesove \& Wallace P. Mullin, Rules, Communication, and Collusion: Narrative Evidence from the Sugar Institute Case, 91 AM. ECON. REV. 379, 393 (2001) (noting that, although "wholesale cheating" was punished, "some cheating" was not, and collusion was "(imperfectly) sustained"). 
examples of successful price-fixing or bid-rigging with some cheating. 38 Moreover, some cartels collude on some but not all competitive dimensions. British Airways and its co-conspirators colluded to set passenger fuel charges on air travel between the United States and the United Kingdom but not on the base air fare. ${ }^{39}$ Sotheby's and its auction house co-conspirators colluded to set the commission charged to sellers but not the commissions charged to buyers. 40

Imperfect coordination can also exist outside of express cartels. Coordinated prices probably fell short of monopoly levels in the brewing, airlines, cellular telephone, hospital, and urban gasoline industry examples that were the subject of empirical studies we previously discussed. ${ }^{41}$ Empirical studies have also identified markets such as the 19th-century railroad industry in which coordinated outcomes in some periods were punctuated by occasional price wars in others ${ }^{42}$ as well as markets in which coordination took place on some but not all competitive dimensions. 43

38 B. Douglas Bernheim \& Erik Madsen, Price Cutting and Business Stealing in Imperfect Cartels, 107 AM. ECON. REV. 387, 390-93 (2017) (describing cheating in various cartels, including a lysine cartel, a food flavor-enhancing nucleotide cartel, a citric acid producers' cartel, the Sugar Institute cartel, and the OPEC cartel).

39 The airlines also colluded to set cargo shipment rates on the same routes. Plea Agreement at 3 6, United States v. British Airways PLC, No. 07-183 (D.D.C. Aug. 23, 2007) (describing British Airways's admission of guilt as to fixing the cargo rate as well as well as the passenger fuel surcharge).

40 Plea Agreement at 2, United States v. Sotheby's Holdings Inc., No. 00-1081, 2000 WL 35630180 (S.D.N.Y. Oct. 5, 2000).

41 In general, one would expect imperfect coordination to be more likely when oligopolists coordinate by identifying a focal outcome, as through price leadership, rather than by explicitly communicating. Explicitly discussing terms of coordination would likely better reach the joint profit-maximizing outcome, but would also risk antitrust enforcement under Section 1 of the Sherman Act. See Baker, supra note 7, at 165 n.43 ("[T]he feasible set of coordinated equilibria . . . that are consistent with a plausible focal rule. . . . need not contain the joint profit-maximizing equilibrium."); MARSHALL \& MARX, supra note 22, at 16 (arguing that coordination without explicit communication tends to allow "[d]eviations induced by self-interest profit maximization [to] creep into [firms'] conduct, and joint profits will fall short of monopoly levels").

42 See generally Glenn Ellison, Theories of Cartel Stability and the Joint Executive Committee, 25 RAND J. ECON. 37 (1994) (studying the Joint Executive Committee, an 1880s railroad cartel); Robert H. Porter, On the Incidence and Duration of Price Wars, 33 J. INDUS. ECON. 415 (1985) (same); Robert H. Porter, A Study of Cartel Stability: The Joint Executive Committee, 1880-1886, 14 BELL J. ECON. 301 (1983) (same). This phenomenon has also been observed in other industries. See, e.g., Jonathan B. Baker, Identifying Cartel Policing Under Uncertainty: The U.S. Steel Industry, 1933-1939, 32 J.L. \& ECON. S47, S67, S71 (1989) (finding that occasional price wars in response to unexpected declines in demand (that is, marketplace punishments) supported coordination in the steel industry during the late 1930s); Timothy F. Bresnahan, Competition and Collusion in the American Automobile Industry: The 1955 Price War, 35 J. INDUS. ECON. 457, 471-72 (1987) (finding evidence suggesting that auto makers' coordinated behavior was briefly interrupted by competitive behavior before returning to coordination).

43 Frode Steen \& Lars Sørgard, Disadvantageous Semicollusion: Price Competition in the Norwegian Airline Industry (NHH Dept. of Econ., Discussion Paper No. 27 2012, 2012), https://ssrn.com/abstract=2205825 [https://perma.cc/B363-4DSL]. 


\section{B. Economic Theory}

Economic theory looks at coordinated outcomes resulting from strategic conduct in two general ways. In one perspective, oligopolists are seen as collectively working towards a market outcome (for instance, a price level and an allocation of market shares), constrained by the need to design or at least identify intended responses to cheating on that outcome that are both credible and sufficiently punitive to minimize the cheating concern. ${ }^{44}$ Oligopolists are usually viewed as focusing on sustainable (self-enforcing) market outcomes that maximize profits, though that focus is not essential to this perspective.

In the other perspective, oligopolists' natural and predictable business responses to one another's price changes are the starting point, and a coordinated outcome emerges organically from the interplay of those responses. ${ }^{45}$ Substantial coordination can arise in such a framework, but there is no expectation that the coordinated outcome would maximize anything.

When coordinated outcomes arise from purposive conduct, oligopolists consciously or purposively put in place responses that discourage pricecutting because they collectively want the resulting high prices and are trying to make them stick. This path to coordination involves some activity aimed at reaching consensus on terms of coordination and enforcing that consensus. ${ }^{46}$ This may involve determining the prices the firms will each charge, the output they will each produce, or the customers they will each serve. It may also involve clarifying how they will define, diagnose and punish cheating. Simple economic models often assume that cheating on the consensus by price-cutting will be punished by vigorous retaliatory price cuts, though other punishment strategies are also possible. 47 We will occasionally

44 In technical language, economists taking this perspective model coordination as a choice of a subgame-perfect equilibrium of a repeated game. Often the focus is on outcomes that maximize profits (or something else) among the subgame-perfect equilibria. For recent examples of economic discussions of antitrust policy that view coordination through this lens, see generally Robert $\mathrm{H}$. Porter, Mergers and Coordinated Effects, INT'L J. INDUS. ORG. (forthcoming 2020) (on file with authors); Marc Ivaldi, Bruno Jullien, Patrick Rey, Paul Seabright \& Jean Tirole, The Economics of Tacit Collusion: Final Report for DG Competition, European Commission (IDEI, Working Paper No. 186, 2003), https://ec.europa.eu/competition/mergers/studies_reports/the_economics_of_tacit_collusion _en.pdf [https://perma.cc/RBC6-LMHQ].

45 In technical terms, this approach calls on the ideas of conjectural variations.

46 Successful coordination also requires that the outcome not be entirely undermined by the entry of new competitors or expansion by noncoordinating rivals. E.g., Levenstein \& Suslow, supra note 27 , at 44 (noting that coordination is threatened by "entry (or expansion) by non[-coordinating] firms"). We assume throughout that coordinating firms are free from new competition or can deter it, at least to a degree that makes coordination among them profitable and of concern.

47 When the major airlines went beyond matching rival fare cuts to reduce fares on routes important to the rivals, see supra text accompanying note 1 (discussing conduct by airlines subject to Justice Department enforcement separately in the 1990 s and the 2010s), they were plausibly engaging in purposive conduct. 
use the term "purposive coordination" as shorthand for coordinated outcomes arising from purposive conduct.

A prominent, though simplified, theoretical model of purposive oligopoly conduct finds that even hundreds of rival firms interacting repeatedly can sustain monopoly prices without creating net incentives to cheat. ${ }^{48}$ Coordinated outcomes often remain feasible even after adding to the model complications like differences across firms in costs and product features, uncertainty about demand, and slowed or limited punishment responses to rival cheating. ${ }^{49}$ The theoretical literature also recognizes that coordinated conduct could be limited to some but not all competitive dimensions..$^{50}$

Purposive coordination includes, but is broader than, expressly collusive conduct such as price-fixing and market division. Much discussion of "tacit collusion" in antitrust commentary explores how firms might purposively find their way toward a consensus plan and enforce it through price reactions without necessarily engaging in conduct that would violate the Sherman Act. ${ }^{51}$ By defining "coordinated" outcomes in economic terms, we include, but do not limit the concept to, outcomes that result from "collusion": a legal term that usually carries the idea of an agreement, 52 which is a predicate for liability under Section 1 of the Sherman Act.53 Even when strategic conduct is purposive, if consensus high prices are reached through leader-follower pricing conduct, that outcome

48 Carl Shapiro, Theories of Oligopoly Behavior, in 1 HANDBOOK OF INDUSTRIAL ORGANIZATION 329, 365-66 (Richard Schmalensee \& Robert Willig eds., 1989).

49 See, e.g., Edward J. Green \& Robert H. Porter, Noncooperative Collusion Under Imperfect Price Information, 52 ECONOMETRICA 87, 89-94 (1984) (identifying the feasibility of coordination in markets with uncertainty about demand).

50 See, e.g., Frode Steen \& Lars Sørgard, Semicollusion, 5 FOUND. \& TRENDS MicrOECONOMICS 153, 165-66 (2009) (describing the theory of coordination on one choice variable, a dimension of rivalry, while competing on others); David T. Levy \& James D. Reitzes, Basing-Point Pricing and Incomplete Collusion, 33 J. REgional SCI. 27, 29-33 (1993) (same); Chaim Fershtman \& Neil Gandal, Disadvantageous Semicollusion, 12 INT'L J. INDUS. ORG. 141, 152 (1994) (same).

51 Since the mid-197os, under the influence of the Chicago approach to antitrust, the term "tacit collusion" has come to mean no more than an agreement proved through circumstantial evidence. Baker, supra note 7 , at 145 . As a matter of logic, however, an express agreement (in which the parties provide each other with explicit assurances, usually verbal, that they will carry out their promises) proved through circumstantial evidence is not the same as a tacit understanding (in which no such assurances are given). Id. at 145 n.7.

$52 \mathrm{Id}$. at $152 \mathrm{n}$.16. In our framework, express collusion can be understood as purposive strategic behavior in which equilibrium selection involves conscious and explicit scheming, most likely through talking. An "agreement" can be understood as a coordinated outcome reached through what one of us has termed the "forbidden process" of negotiation and exchange of assurances, rather than through the sort of leader-follower behavior that firms cannot be expected to avoid and that courts cannot be expected to remedy. Id. at 179, 191.

5315 U.S.C. $\S 1$ (2018). We follow the common practice of summarizing the "contract, combination[,] . . . or conspiracy" language of the statute through the term "agreement." Id. 
would probably not be deemed to have resulted from an "agreement." ${ }_{54}$ Coordinated outcomes arising from nonpurposive strategic conduct are even less likely to satisfy the agreement requirement of Section 1.

When oligopolists respond to one another's price changes in a natural business way, they are engaged in nonpurposive strategic conduct. Although those reactions are not part of an express scheme or an informal effort to develop a common understanding or deter price-cutting, those predictable responses will generally affect oligopolists' incentives and may well discourage price-cutting. As the 2010 Horizontal Merger Guidelines note, coordination "includes situations in which each rival's response to competitive moves made by others is individually rational and not motivated by retaliation or deterrence nor intended to sustain an agreed-upon market outcome, but nevertheless emboldens price increases and weakens competitive incentives to reduce prices or offer customers better terms." 55 We call this type of strategic conduct "nonpurposive" (and occasionally refer to coordinated outcomes arising from such conduct as "nonpurposive coordination"). As was recognized by Donald Turner in the midtwentieth century, ${ }^{56}$ nonpurposive coordination is likely to be common in oligopoly and difficult to prohibit-difficult even for intelligent oligopolists to avoid and difficult for judges to remedy.

To motivate our view that coordination from nonpurposive conduct is common, we begin by observing that oligopolists typically monitor and respond to rivals' price changes. ${ }^{57}$ When one firm cuts its price and another responds naturally, as we put it above, we have in mind that the second firm is responding in a predictable way to an objective change in its business environment. The second firm might naturally respond by cutting price, for example, if it expects the first firm's new price to persist, if the second firm loses some of what it had been thinking of as reliable customers, or if it learns from observing the price reduction that the first firm has lower costs or a different business strategy than it had believed. These responses need not be part of an effort to enforce a consensus on terms of coordination; they are just what firms naturally and predictably do. Not surprisingly, the economics

54 Richard Posner and Donald Turner famously debated whether "conscious parallelism," including leader-follower conduct, should be deemed an "agreement" under the Sherman Act. See GAVIL ET AL., supra note 28 , at 320-24 (surveying the Turner-Posner debate). Turner's positionthat it would be impractical for courts to interpret the Sherman Act to reach such conduct, even when the economic consequences mirrored those of express collusion, because the conduct is unavoidable and courts cannot be expected to devise viable remedies that avoid chilling beneficial conduct-has largely prevailed. $I d$. at 322 .

552010 HMG, supra note 13, at 24-25.

56 See supra notes $16 \& 54$ and accompanying text.

57 Such conduct is a common source of evidence in market definition, where it is a basis for inferring what firms think about buyer substitution patterns. Jonathan B. Baker, Market Definition: An Analytical Overview, 74 ANTITRUST L.J. 129, 141 (2007). 
literature has long recognized that objective sources of oligopoly dynamics such as these can lead to coordinated outcomes. ${ }^{58}$

Prominent theoretical models of nonpurposive oligopoly conduct suggest the plausibility of coordinated outcomes. In one, firms match rivals' competitive decisions before customers react (so-called "quick responses").59 Edward Chamberlin's simplified and informal quick response model, in which he pointed out that oligopolists could have strong incentives to charge the monopoly price, ${ }^{60}$ was influential in shaping the skepticism about oligopoly that commonly characterized courts and commentators during antitrust's structural era, which dated from the 1940s through the late 1970s.61

In another prominent model of nonpurposive oligopoly conduct, ${ }^{62}$ each firm chooses its price based on (reacting to) the price that its rival most recently chose and that will briefly persist, but does not otherwise consider how the firm's rival behaved in the past.63 In this model, Eric Maskin and

58 See, e.g., Eric Maskin \& Jean Tirole, A Theory of Dynamic Oligopoly, I: Overview and Quantity Competition with Large Fixed Costs, 56 ECONOMETRICA 549, 553 (1988); Edward H. Chamberlin, Duopoly: Value Where Sellers Are Few, 44 Q.J. ECON. 63, 65, 88 (1929). The economics literature has similarly identified oligopoly dynamics arising from objective sources in other contexts. See generally Joseph Farrell \& Carl Shapiro, Dynamic Competition with Switching Costs, 19 RAND J. ECON. 123 (1988) (identifying switching costs as the objective source); Alan Beggs \& Paul Klemperer, MultiPeriod Competition with Switching Costs, 6o ECONOMETRICA 651 (1992) (same); Michael L. Katz \& Carl Shapiro, Product Introduction with Network Externalities, 40 J. INDUS. ECON. 55 (1992) (identifying network effects as the objective source).

59 Quick rival responses are plausibly understood as nonpurposive reactions to the immediate competitive environment, although they could also arise from purposive conduct. See generally Robert M. Anderson, Quick-Response Equilibrium (Oct. 26, 1985) (unpublished manuscript) (on file with authors); V. Bhaskar, Quick Responses in Duopoly Ensure Monopoly Pricing, 29 ECON. LETTERS 103 (1989).

60 Chamberlin, supra note 58 , at 86, 89. See generally EDWARD HASTINGS CHAMBERLIN, THE THEORY OF MONOPOLISTIC COMPETITION 48 (8th ed. 1962) (describing the tendency to charge the monopoly price).

61 During that period, the courts and antitrust enforcers were even hostile to small horizontal mergers in markets that would be considered unconcentrated by today's standards. See, e.g., United States v. Von's Grocery Co., 384 U.S. 270 (1966); U.S. Department of Justice, Merger Guidelines (1968), reprinted in 4 Trade Reg. Rep. (CCH) I 13,101 (showing antitrust enforcers' hostility to horizontal mergers between firms with low shares in less concentrated markets).

62 See Maskin \& Tirole, supra note $5^{8}$. In the model, the timing of adjustment costs creates short term commitments, which affect rival reactions. See Engelbert J. Dockner, A Dynamic Theory of Conjectural Variations, 40 J. INDUS. ECON. 377 (1992) (exploring the relationship between dynamic oligopolistic competition and static conjectural variations equilibria in a model with adjustment costs); Luis M.B. Cabral, Conjectural Variations as a Reduced Form, 49 ECON. LETTERS 397, 397-98 (1995) (identifying a dynamic game where the conjectural variation solution is an exact reduced form); $c f$. Zach Y. Brown \& Alexander MacKay, Competition in Pricing Algorithms 3-5 (Harvard Bus. Sch., Working Paper No. 20-067, 2020) (finding that when firms compete by adopting simple pricing algorithms that are linear in rivals' prices, thus making short-run commitments, conjectural variation equilibria can arise with prices that exceed those arising in static Nash equilibria when firms choose price).

63 These firms employ "Markov strategies": they base their decisions on the current state of the world only. Bygones are bygones: decisions do not depend on what rivals did in the past, except insofar 
Jean Tirole find that oligopolists will sustain high prices when each firm correctly expects that if it cuts its price, its rival will cut price too. That expectation dilutes the benefit from such discounting. ${ }^{64}$ Maskin and Tirole analyze these simple price-cutting reactions as natural responses in the competitive environment (hence nonpurposive conduct), as distinct from efforts to deter, reward, or punish rivals (which would be purposive conduct). In their analysis, "cutting one's own price in response to another firm's price cut is not carrying out a threat at all. It is merely an act of self-defense, an attempt to regain lost customers." Put by Maskin and Tirole in another way, "the reaction is a response only to the other firm's price cut and not to earlier history or to one's own past prices." 65

To help clarify the distinction between purposive and nonpurposive oligopoly conduct, suppose we have access to documents, emails, and testimony from the firms in an oligopoly. If the evidence shows that executives consider how rivals would respond when choosing key decision variables like prices and output, that suggests that firm conduct is strategic without distinguishing between purposive and nonpurposive conduct. Suppose, further, that we can query the executives at one firm candidly about what they think rivals would do were their firm to, for example, lower price, and learn that they expect rivals to lower prices in response. If that expectation discourages the first firm from cutting price in the first place, keeping prices high, the outcome is coordinated.

Whether we would characterize the strategic conduct as purposive or nonpurposive depends in part on its rationale. 66 If, for example, the

as those past actions objectively affect the current competitive environment. Eric Maskin and Jean Tirole have explained that "Markov strategies seem at times to accord better with the customary conception of a reaction in the informal industrial organization literature than do, say, the reactions emphasized in the repeated game (or 'supergame') tradition." Maskin \& Tirole, supra note 58 , at 553.

64 The firms do not necessarily expect their rivals also to match if they raise price. Such asymmetric reactions are sometimes termed "kinked demand" strategies, although though firmspecific demand curves in the models are not necessarily kinked: more elastic with respect to price increases than with respect to price declines.

65 Maskin \& Tirole, supra note 58 , at 553 . Maskin and Tirole also show that in a continuous model this behavior is a limiting case of the outcome of finite-horizon versions of their game, which we can interpret as showing that the behavior is essentially the result of recursion from Stackelbergtype nonstrategic responses. Eric Maskin \& Jean Tirole, A Theory of Dynamic Oligopoly, III: Cournot Competition, 31 EUR. ECON. REV. 947, 958 (1987). Zach Brown and Alexander MacKay developed another model of nonpurposive coordination. They suppose that firms compete by selecting simple pricing algorithms that are linear in rivals' prices and that those choices of algorithms are themselves made nonstrategically. The "resulting game resembles competition with conjectural variations" and leads to coordinated outcomes, with prices that exceed those generated in static Nash-Bertrand models. Brown \& MacKay, supra note 62, at 3 n.5.

66 See supra notes 15 and 17 (describing features of strategic conduct that may suggest it is purposive). Some forms of conduct may be hard to classify, however. See, e.g., supra note 15 (providing an example in which price-leadership could be purposive or nonpurposive). 
executives, still speaking candidly, expect rivals to match simply because they would lose too many customers if they kept their price high, then the strategic conduct may be nonpurposive. If instead, for example, they expect rivals to match because the rivals think that doing so will make price-cutting less profitable for the first firm, then the strategic conduct may be purposive. ${ }^{67}$

Or we might ask a firm's executives why their own firm matches when rival firms cut prices. If the executives say, for example, "we need to maintain our policy of always matching rivals' prices (regardless of whether it would seem to make business sense)" 68 or "we want to send a signal that we would like to avoid a price war," the strategic conduct may be purposive. ${ }^{69}$ However, if they say, "we see that the overall industry price level has declined, and will lose many customers unless we reduce price in response" or "we see that our rivals have reduced their excess production capacity, making it likely that they will not expand output much when we reduce our output," the strategic conduct may be nonpurposive.

As previously mentioned, purposive and nonpurposive conduct may coexist. Therefore, identifying one type of strategic conduct does not preclude the possibility that the oligopolists are also engaged in the other. If conduct is strategic, whether purposive or nonpurposive, and, in addition, prices exceed a coordination-free benchmark level, we would describe the outcome as coordinated.

\section{Summary}

Empirical studies, experimental results, real-world examples, and economic theory consistently indicates that oligopolies can sustain coordinated outcomes that restrict competition and yield higher prices and other harms to buyers. While coordination is not ubiquitous in oligopoly markets, it often arises, it does not require express collusion, and it need not be perfect (joint profit-maximizing). Oligopolistic coordination-whether joint profit-maximizing or, more likely, imperfect or incomplete relative to

67 In terms of Thomas Schelling's distinction, described supra note 15, communication of the first expectation (nonpurposive conduct) would be a warning while communication of the second (purposive conduct) would be a threat, at least if the rivals interpreted the intention to match as a credible commitment.

68 Similarly, if the firm had made a contractual or public commitment to match its rivals' prices, that may suggest its price-matching conduct is purposive.

69 If a firm systematically responds to the loss of a customer to a specific rival by offering low prices to the rival's largest customer (but not offering discounts to other prospective customers), that behavior too might suggest that strategic conduct is purposive, as it appears not to make business sense other than through disciplining the rival's conduct. See supra notes 15 and 17 (describing features of strategic conduct that may suggest it is purposive). 
monopoly outcomes-is a serious problem and thus an appropriate concern of antitrust enforcement.

\section{The Dubious ARgument FOR SKEPticism ABOUT OligOPOLY COORDINATION}

In contrast to the above, an influential strand of antitrust thinking associated with the Chicago school of antitrust views oligopolies benignly. According to Robert Bork, "[o]ligopolistic structures probably do not lead to significant restrictions of output,"70 and "non-collusive oligopolistic behavior, to the extent that it exists at all (and I am not persuaded that such behavior occurs outside of economics textbooks), rarely results in any significant ability to restrict output." 71 To similar effect, Richard Posner argued that cartels are "usually quite unstable" 72 and that outside of the most concentrated oligopolies, the "immense practical difficulties" oligopolists face in reaching cartel prices and the problem of maintaining a cartel "in the face of the inevitable self-destructive tendencies" cannot be solved without "the kind of elaborate apparatus of communication and enforcement that is bound to be detected eventually." 73

According to such Chicagoans, antitrust should have little concern with oligopoly, outside of prosecuting express agreements to fix prices or divide markets or challenging mergers to near-monopoly, because oligopolies usually perform competitively absent express collusion and express collusion is difficult. This argument relies on three claims, each highly questionable.

The first claim is that absent coordination, oligopolies perform competitively. Even if "coordination" were interpreted broadly, as we do (but the Chicagoans may not), this claim ignores the modern economic learning and antitrust experience with unilateral effects: even absent coordination,74

70 ROBERT H. BORK, THE ANTITRUST PARADOX 196 (1978).

$71 \mathrm{Id}$. at 221. Consistent with this analysis, Bork also contended that horizontal mergers in oligopoly markets are unlikely to be harmful unless the merger is to monopoly or near monopoly. Id. Bork used the term "collusive" to refer to express naked horizontal cartels (price-fixing or market division), id. at 263-79, not to refer to the broader concept of coordination we employ.

72 Richard A. Posner, ANTITRUST LAW 53 (1st ed. 1976).

$73 \mathrm{Id}$. at 54 . As does Bork, Posner supposes that oligopolies either compete or collude (either expressly or tacitly). Id. at 40, 47. In the second edition of his book, Posner revised his exposition but continued to question whether oligopolies would succeed in avoiding competition, particularly in markets with more than a few sellers. RICHARD A. POSNER, ANTITRUST LAW 68-69 ( $2 \mathrm{~d}$ ed. 2001).

74 We are referring to static Nash equilibrium when firms choose price or output. When oligopolists are behaving nonstrategically, their prices could be elevated above their costs. We treat such prices as our noncoordination benchmark, not as the outcome of coordinated conduct. 
oligopoly performance is generally imperfect and can often become substantially worse with horizontal mergers well short of a monopoly. 75

The Chicagoans' second claim is that coordinated outcomes from nonpurposive strategic conduct can simply be ignored. 76 When Donald Turner described oligopoly outcomes, he had nonpurposive conduct in mind. ${ }^{77}$ Yet Richard Posner, criticizing Turner's views from a Chicago perspective, appears to take as given that Turner is describing purposive conduct. ${ }^{78}$ This claim is the likely basis for the Chicagoan understanding of "tacit collusion" as express collusion demonstrated by circumstantial evidence. 79

The third claim is that purposive strategic conduct, including illegal collusion, is difficult, risky, and unstable-and therefore rare. Proponents of this view reference genuine challenges in achieving coordinated outcomes through purposive strategic conduct but overstate how difficult those challenges are to surmount.

The challenges may include overcoming possible differences in incentives among oligopolists, short-run incentives to cheat on the coordinated outcome, difficulties in diagnosing which firm (if any) has done so, and incentives to shy away from imposing costly punishments. These and similar factors can indeed limit how widespread and effective purposive coordination is. But, modern theoretical literature analyzes these challenges and finds that coordinated outcomes from purposive conduct can often be achieved and sustained, 80 and empirical, real-world, and experimental evidence demonstrates that coordination is often feasible and durable. 81 Modern

75 The theoretical economic literature that analyzes the Nash equilibria of static models prominently highlights the Bertrand paradox, by which even as few as two firms will reach an equilibrium where price is equal to cost. See, e.g., JEAN Tirole, ThE THEORY OF InDUSTRIAL ORGANIZATION 209-11 (1988) (discussing the Bertrand paradox). This outcome is the Nash equilibrium of a static oligopoly model in which homogeneous firms have identical and constant unit costs, and price is the decision variable. The Bertrand paradox is called a paradox "because it is hard to believe that firms in industries with few firms never succeed in manipulating the market price to make profits." Id. at 210-11. The theoretical literature analyzing the Nash equilibria of static models also prominently discusses the Cournot model and the Bertrand model with product differentiation-each of which shows how static oligopoly interaction can elevate price above cost when a small change in a firm's decision variable in the direction of increased competition would not divert all sales to that firm.

76 See Posner, supra note 21, at 1569 (indicating Posner's "doubts that the interdependence theory of oligopoly provides an adequate explanation as to why prices in oligopolistic industries should exceed competitive levels").

77 See supra note 16 and accompanying text.

78 See Posner, supra note 21, at 1566-69 (arguing that Turner does not adequately account for oligopolists' incentives to undermine coordination through cheating). Posner acknowledges a collaboration with Aaron Director and a great debt to George Stigler, both of whom, like Posner, are associated with the Chicago school. Id. at $1562 \mathrm{n.}$.

79 See supra note 51 and accompanying text.

80 See supra notes $46-50$ and accompanying text.

81 See supra Section I.A. 
economics thus accepts that a broad range of outcomes are possible in oligopoly markets - prominently including coordinated outcomes.

Overstated obstacles to coordination arising from purposive conduct include the following:

(1) Explicit communication (talking) is vulnerable to detection and prosecution by antitrust enforcers. ${ }^{82}$ Talking may indeed make coordination easier, but it is not always detectable by enforcers and not always necessary for oligopolists to reach coordinated outcomes through purposive conduct. Consensus terms of coordination can be reached without communication when there are other ways to make an outcome focal, as through leader-follower conduct or market allocation based, for example, on historical patterns.

(2) Oligopolists' divergent interests make it hard for them to reach consensus terms, especially without talking. Divergent interests can indeed pose a challenge for oligopolists seeking to reach terms of coordination, especially when the number of firms rises and firms compete on multiple dimensions. 83 But there is no reason to think that this challenge is routinely or reliably prohibitive. For example, oligopolists can simplify coordination tasks, as by standardizing product dimensions or grandfathering in prior price differentials; or, they may instead attempt to minimize competition through means such as market division or reciprocal royalties rather than price-fixing. ${ }^{84}$

(3) Successful coordination may require oligopolists to reach consensus on the terms and enforcement of planned punishment strategies, as well as reach consensus on the intended high prices and individual firm outputs. If oligopolists adopted the complex "optimal punishment schemes" identified in the theoretical economics literature, they would indeed often need to engage in such negotiations. But coordination can often be sustained with simple threats or punishment schemes, including simply jeopardizing the profitable coordination, that can be identified without detailed (or perhaps any) communication. 85

\footnotetext{
82 See supra note 41 .

83 GAVIL ET AL., supra note 28 , at 296-97.

84 See supra notes $37-39$ and accompanying text.

85 The early experimental literature on cooperation in repeated prisoners' dilemmas found that strategies that combined being nice, retaliatory, forgiving, and clear had particular success in eliciting long-term cooperation. ROBERT AXELROD, THE EVOLUTION OF COOPERATION 54 (1984). The most notable example was the simple "TIT FOR TAT" algorithm, which cooperates on the first move and practices reciprocity for both cooperation and defection thereafter. Id. at 118; cf. WILLIAM POUNDSTONE, PRISONER'S DILEMMA 106-18 (1992) (describing an early experiment in which two economists playing a repeated prisoners' dilemma game induced trust and achieved some cooperation). Moreover, the early game theoretic literature on collusion found that fear of reversion to static Nash behavior-a natural result of a coordinated consensus breaking down-is often sufficient to deter cheating. Indeed, antitrust practitioners often center their analyses on that possibility rather than on more sophisticated punishment schemes. Joseph Harrington has observed that "cartels occur most frequently in markets for which buyers' decisions are heavily based on price." Joseph E. Harrington, Jr., Organisation for Economic Co-operation and Development [OECD],
} 
(4) Even after reaching consensus, firms are likely to cheat on it, especially when firms can find ways to do so that delay or avoid detection. Proponents of this view rely on George Stigler's observation that even firms with few rivals could have strong incentives to undercut collusive prices, leading to competitive outcomes. ${ }^{86}$ Short-term incentives to cheat on the consensus do indeed create a constraint or challenge for collusion, but this challenge can be overcome-as is evident from the prevalence and durability of cartels, the theoretical economic literature showing that collusion can persist even with dozens or hundreds of rivals and even with severe difficulties in identifying defection and defectors, and the theoretical and empirical studies showing how firms can achieve coordinated outcomes through purposive conduct in the face of uncertainty about rival behavior or difficulty monitoring that behavior on all competitive dimensions. ${ }^{87}$ Firms may also be able to improve detection and responses to cheating through openly adopted practices like product standardization, posting prices, or contractual commitments to match rivals' prices. 88

Despite its reliance on these questionable premises, the Chicagoan benign view of oligopolies has circumscribed the range of antitrust enforcement. It has led the enforcement agencies (whether based on their own judgment or on their expectations of courts' beliefs) to relax (i.e., increase over time) the concentration threshold above which horizontal mergers would be closely scrutinized and/or likely challenged. 89

Thoughts on Why Certain Markets Are More Susceptible to Collusion and Some Policy Suggestions for Dealing With Them, at 6, OECD doc. DAF/COMP/GF(2015)8 (Oct. 19, 2015), http://www.oecd.org/officialdocuments/publicdisplaydocumentpdf/?cote=DAF/COMP/GF(2015) 8 \&docLanguage $=$ En $[$ https://perma.cc/TUS $5-76 \mathrm{FH}$ ]. If static Nash behavior in such markets is very competitive, as simple oligopoly models with prices as decision variables suggest, then reversion to static Nash behavior could support substantial price elevation in a supergame model, because in those models the degree of cooperation is limited by the strength of the incentive to avoid breakdown of cooperation. By contrast, the complex "optimal punishment schemes" that game theorists have analyzed would likely require communication to implement. On the design of optimal punishment schemes, see generally Dilip Abreu, On the Theory of Infinitely Repeated Games with Discounting, 56 ECONOMETRICA 383 (1988).

86 See George J. Stigler, A Theory of Oligopoly, 72 J. POL. ECON. 44, 46 (1964) (highlighting oligopolists' incentive to cheat on a collusive outcome through secret price-cutting, while recognizing that under some circumstances, coordination could succeed). Richard Posner explicitly acknowledged the influence of Stigler's model on his views. POSNER, supra note 72, at 47.

87 See supra notes $37-43,49-50$ and accompanying text.

88 See supra note 35 and accompanying text. To similar effect, when distributors or buyers of intermediate goods from multiple sources tell suppliers about discounts received from rival suppliers-which is often a natural negotiating tactic-they can facilitate (purposive) supplier coordination by speeding the detection and response to cheating. More generally, firms can deter cheating, thereby facilitating coordination, by increasing the transparency of what otherwise might be secret transactions.

89 The threshold above which acquisitions would be scrutinized strictly "involved a reduction of the number of significant competitors in the following manner: 1960s (12 to 11), 1970s (9 to 8), 1980 os (6 to 5), 1990 ( (4 to 3), 2000s (4 to 3)." William E. Kovacic, Assessing the Quality of Competition 
The Chicago perspective also led the Supreme Court in Brooke Group to take the view that oligopoly coordination is hard to achieve and unstable. ${ }^{90}$ The Court explained, seeming to focus on purposive but not explicit coordination, that the "anticompetitive minuet" of raising prices through signaling "is most difficult to compose and to perform, even for a disciplined oligopoly" because signals "are a blunt and imprecise means of ensuring smooth cooperation, especially in the context of changing or unprecedented market circumstances." 91 In addition, according to the Court, there is a "high likelihood that any attempt to discipline will produce an outbreak of competition."92 Moreover, the details of the Supreme Court's explanation of why the industry was not congenial to coordination "has a distinctly Chicago flavor" not informed by insights from modern oligopoly theory. ${ }^{93}$ While modern courts accept the possibility of oligopolistic coordination, and are willing to find competitive harm from conduct in highly concentrated markets, ${ }^{94}$ they may nevertheless be led by Brooke Group to interpret the

Policy: The Case of Horizontal Merger Enforcement, 5 COMPETITION POL'Y INT'L 129, 143 (2009). Data released by the Federal Trade Commission about the disposition of horizontal merger investigations subject to "second requests" between 1996 and 2011 suggest that the likelihood of a challenge rises as (the Commission's view of) the number of significant rivals falls, and that a challenge becomes more likely than not when the acquisition reduces the number of significant rivals from 5 to 4. FED. TRADE COMM'N, HORIZONTAL MERGER InVESTIGATION DATA: FisCAL YEARS 1996-2011 12 tbl.4.1 (2013), https://www.ftc.gov/sites/default/files/documents/ reports/horizontal-merger-investigation-data-fiscal-years-1996-2011/130104horizontalmergerreport. pdf [https://perma.cc/JL $\mathrm{U}_{5} \mathrm{U}_{2} \mathrm{HN}$ ]. The likelihood of FTC enforcement when concentration is below this threshold has declined over time. JOHN KWOKA, MERGERS, MERGER CONTROL, AND REMEDIES 24-33 (2015). The Justice Department likely behaves similarly to the FTC, but the former has not released comparable data.

90 Brooke Grp. Ltd. v. Brown \& Williamson Tobacco Corp., 509 U.S. 209, 227-28, 240 (1993). In dissent, Justice Stevens argued that the Court was wrong to suppose that the plaintiff "had the burden of proving either the actuality of supracompetitive pricing, or the actuality of tacit collusion." Id. at 258 (Stevens, J., dissenting).

91 Id. at 227-28. The Court distinguished this conduct from "express coordination." Id. at 227. Justice Stevens responded by taking a broader view of coordination, more consistent with ours. Id. at 257 (Stevens, J., dissenting) ("I would suppose . . . that the professional performers who had danced the minuet for 40 to 50 years would be better able to predict whether their favorite partners would follow them in the future than would an outsider, who might not know the difference between Haydn and Mozart.").

$92 \mathrm{Id}$. at 228.

93 Jonathan B. Baker, Predatory Pricing After Brooke Group: An Economic Perspective, 62 ANTITRUST L.J. 585, 600 (1994).

94 See, e.g., FTC v. CCC Holdings Inc., 605 F. Supp. 2 d 26 (D.D.C. 2009) (enjoining a merger reducing the number of major firms three to two on a coordinated-effects theory); United States $v$. H\&R Block, Inc., 833 F. Supp. 2d 36 (D.D.C. 2011) (same); see also In re Text Messaging Antitrust Litigation, 782 F.3d 867, 873-74 (7th Cir. 2015) (accepting that the oligopolists coordinated through leader-follower pricing but declining to infer an agreement among them in violation of the Sherman Act from circumstantial evidence). 
evidence against the background of the Chicagoan presumption that oligopolies would be expected to compete strongly. 95

\section{IMPLICATIONS FOR ANTITRUST MERGER ENFORCEMENT}

Notwithstanding the important prophylactic role of merger enforcement, in preventing coordinated effects that would be difficult to challenge under the antitrust laws after the fact, and notwithstanding developments in economic thinking that we have highlighted, coordination has received less attention in antitrust since the 198 os outside of cartel enforcement. ${ }^{96}$ This is evident in the way courts review mergers between rival hospitals. In an influential 1986 opinion upholding an FTC decision blocking a hospital merger, Judge Richard Posner explained that the "ultimate issue" in a horizontal merger case is "whether the challenged acquisition is likely to facilitate collusion." 97 By contrast, in recent hospital merger cases, the primary if not sole competitive effects concern was with unilateral effects. 98

95 While the Court's skepticism about the success of coordination in Brooke Group was offered as a reason not to expect oligopoly recoupment after predatory pricing, it has been understood more broadly. For example, the dissenting judges in the closely divided circuit court in Blomkest Fertilizer, Inc. v. Potash Corp., 203 F.3d 1028 (8th Cir. 2000) (en banc), relied in part on Brooke Group when explaining that higher than competitive prices were implausible in an oligopoly absent an express agreement among rivals because coordination is difficult to achieve and sustain. Id. at 1041-42.

96 Although it is not the focus of our analysis, we note that the courts have also made it more difficult to use Section 1 of the Sherman Act to challenge coordinated oligopoly outcomes. In 1986, the Supreme Court encouraged lower courts to consider the economic plausibility of allegations of conspiracy before inferring a horizontal agreement from circumstantial evidence and reject cases where the plaintiff cannot proffer evidence that "tends to exclude the possibility" of unilateral conduct. Matsushita Elec. Indus. Co. v. Zenith Radio Corp., 475 U.S. 574, 587-88, 596-98 (1986). Although the alleged agreement involved a conspiracy to set prices below cost, a number of lower courts have applied Matsushita's standards in cases involving alleged agreements to raise price. GAVIL ET AL., supra note 28, at 338. Matsushita's call for an assessment of the economic plausibility of plaintiff's conspiracy evidence at the summary judgment stage of litigation has since been extended to the pleading stage of litigation. Bell Atlantic Corp. v. Twombly, 550 U.S. 544, 554-60 (2007). Since Matsushita, courts have commonly considered economic plausibility when deciding whether to infer an agreement from circumstantial evidence. E.g., Stanislaus Food Products Co. v. USSPOSCO Indus., 803 F.3d 1084, 1091 (9th Cir. 2015) (concluding that the alleged conspiracy is economically implausible because the "benefit of this scheme [to a critical alleged coconspirator]. . . is just not apparent"); Blomkest Fertilizer, Inc., 203 F.3d at 1043-44 (noting "situational [plus] factors" including "market structure, motivation, and opportunity" that "make conspiracy possible"). With courts willing to accept dubious Chicagoan arguments skeptical that oligopolies can successfully reach coordinated outcomes, this seemingly neutral economic approach has in practice empowered defendants opposing meritorious coordination cases by giving them an opportunity they did not previously possess to press the arguments that persuaded the Chicagoans that coordinated oligopoly outcomes are hard to reach and sustain.

97 Hosp. Corp. of Am. v. FTC, 807 F.2d 1381, 1386 (7th Cir. 1986) (Posner, J.).

98 E.g., ProMedica Health Sys. v. FTC, 749 F.3d 559, 568-70 (6th Cir. 2014) (analyzing the unilateral effects of a merger between two hospitals in Ohio); Saint Alphonsus Med. Ctr.-Nampa Inc. 
Coordinated effects of horizontal mergers have also been downplayed by the antitrust enforcement agencies. The agencies often focus on unilateral effects even in industries, such as airlines, with histories of coordinated outcomes. ${ }^{99}$ We follow the widespread convention of classifying as a unilateral effect the possibility that all firms' prices change-provided that none of the changes turn on the expected responses of rivals.100

But the merger guidelines have evolved to reflect the changing economic understanding of coordination since the courts and enforcement agencies adopted Chicago school views. The 1982 Merger Guidelines were predicated on a Chicagoan view of oligopolistic coordination. ${ }^{101}$ By contrast, the analytical framework governing coordinated effects set forth in the 1992 Horizontal Merger Guidelines was rooted in the modern economics of coordination through purposive conduct, ${ }^{102}$ and the 2010 Horizontal Merger

v. St. Luke's Health Sys., Ltd., 778 F.3d 775, 786-87 (9th Cir. 2015) (discussing the post-merger entity's power to negotiate higher rates of reimbursement and charge higher rates for ancillary services).

99 Baker, supra note 7, at 116-17. In part, this likely reflects a shift in agency focus to unilateral effects. Unilateral effects became attractive in part because they gave the enforcement agencies a greater ability to understand and explain the mechanism by which competition would be harmed and because economists developed new empirical tools for analyzing unilateral effects that took advantage of new sources of data. Jonathan B. Baker, Why Did the Antitrust Agencies Embrace Unilateral Effects?, 12 GEO. MASON L. REV. 31, 33-36 (2003).

100 To address an often-confusing technical question, unilateral price increases can include nonstrategic responses of nonmerging rivals (such as price increases). In some common models used to simulate unilateral effects, notably static Nash equilibrium models where firms choose price or output, firms act as though they anticipate that rivals will not respond to their decisions but will react rationally to the fact of the merger, so nonmerging firms' choices typically will change. We treat those effects of a merger in such Nash equilibrium models as our noncoordinated benchmark, and would classify those responses as unilateral, not coordinated. Unilateral effects do not assume that nonmerging firms' prices (or outputs) remain constant, but they do assume that those firms pursue "unchanging strategies," meaning roughly that each nonmerging firm's price bears the same relationship to others' (including the merging firms') prices as it would have done absent the merger. See Gregory J. Werden \& Luke M. Froeb, Unilateral Competitive Effects of Horizontal Mergers, in HANDBOOK OF ANTITRUST ECONOMICS 43, 43 (Paolo Buccirossi, ed. 2008) (suggesting that merger effects are "coordinated" only if they shift the (confusingly named) "reaction functions" of nonmerging parties, and using the language of "unilateral effects" to describe the outcome when nonmerging rivals respond to an anticipated price increase by the merged firm by raising price too, so long as the nonmerging firms pursue "unchanging strategies").

101 Paul T. Denis, Market Power in Antitrust Merger Analysis: Refining the Collusion Hypothesis, 60 ANTITRUST L.J. 829, 829-30 (1992). Cf. William F. Baxter, Responding to the Reaction: The Draftsman's View, 71 CALIF. L. REV. 618, 626 (1983) (acknowledging the influence of Stigler's analysis of oligopolies in the development of concentration standards).

1021992 HMG, supra note 14, at 18-22. More specifically, the discussion of coordinated effects in the 1992 Guidelines was based on the idea that coordinated outcomes were those subgame perfect equilibria of infinitely repeated games that are less competitive than static oligopoly outcomes. See Robert D. Willig, Merger Analysis, Industrial Organization Theory, and Merger Guidelines, BROOKINGS PAPERS ON ECON. ACTIVITY: MICROECONOMICS, 1991, at 281, 291-92; Baker, supra note 7, at 152 n.16. These articles were written around the time that those authors worked on drafting the 1992 Guidelines. 
Guidelines broadened the definition of coordinated effects further to incorporate nonpurposive strategic ("parallel accommodating") conduct. ${ }^{103}$

How should antitrust enforcers and courts address coordination when evaluating horizontal mergers in light of the modern economic literature? Here, we suggest that a detailed competitive effects analysis should turn on whether the coordinated effects concern principally involves purposive or nonpurposive strategic conduct. Enforcers should, of course, be open to both concerns, which are not mutually exclusive. ${ }^{104}$

We emphasize, however, that both types of strategic conduct and resulting coordinated effects can be expected to be more likely or more substantial the greater the level and increase in market concentration. This supports a structural merger policy, by which market concentration statistics trigger a presumption of coordinated effects-while also suggesting more detailed ways of evaluating the likelihood of coordinated effects in the event the plaintiff's prima facie case based on concentration is not strong or successfully questioned by the merging firm defendants. ${ }^{105}$

\section{A. Coordinated Effects Involving Purposive Strategic Conduct}

In considering whether a merger would facilitate more effective purposive strategic conduct, we recommend that enforcers and courts look to identify mergers that weaken a constraint on the ability of coordinating firms to approach more closely the joint profit-maximizing outcome or make coordination more likely or more stable. This approach is suggested by

1032010 HMG, supra note 13, at 24-25 (identifying as "coordinated" effects conduct that is profitable only because of rival reactions, as in the 1992 Guidelines, while explicitly incorporating "parallel accommodating conduct" within that definition and distinguishing it from a "common understanding that is not explicitly negotiated but would be enforced by the detection and punishment of deviations that would undermine the coordinated interaction"); see Carl Shapiro, Deputy Assistant Att'y Gen. For Econ., Antitrust Div., U.S. Dep't of Justice, Remarks at the ABA Section of Antitrust Law Fall Forum: Update from the Antitrust Division27-28 (Nov. 18, 2010), https://www.justice.gov/atr/file/518246/download [https://perma.cc/ASZ6-C9KS] (explaining that the 2010 Merger Guidelines recognize parallel accommodating conduct as a form of coordination and providing an example).

104 See supra note 18. For example, if pre-merger firms have reached coordinated outcomes short of joint profit-maximization through nonpurposive conduct, their merger could potentially facilitate purposive coordination (as well as make nonpurposive coordination more effective).

105 Once the plaintiff has satisfied its initial burden of production in a horizontal merger case, the strength of defendants' practical burden of persuasion varies on a sliding scale. "The more compelling the prima facie case," which could be satisfied by relying on a presumption of competitive harm inferred from market concentration, "the more evidence the defendant must present to rebut it successfully." United States v. Baker Hughes Inc., 908 F.2d 981, 991 (D.C. Cir. 1990). Accord FTC v. H.J. Heinz Co., 246 F.3d 708,726 (D.C. Cir. 2001). One district court has interpreted this language to mean that as the plaintiff's prima facie case becomes more compelling, the defendant must show more to meet its burden of production (not just that the defendant must show more to meet its practical burden of persuasion). United States v. H \& R Block, Inc., 833 F. Supp. 2d 36, $72-73$ (D.D.C. 2011). 
economic models in which firms seek to approach that outcome (or another anticompetitive outcome) but are constrained in that attempt because they must reach consensus terms of coordination and deter cheating. ${ }^{106}$ In such models, coordination is constrained either by limitations on the incentive of coordinating firms to punish cheating or by the difficulties they face in identifying coordinated outcomes that would increase the pool of profits from exercising market power without reducing the profits obtained by any one of those firms. This approach allows the plaintiff to explain, and the court to understand, why the merger matters - and not simply to look to the structural presumption that associates higher concentration with greater odds of successful purposive coordination.

Suppose, for example, that all firms sell a single product so interchangeable that one way or another all will charge the identical price. Thus, in practice, coordinating firms can improve the terms of coordination only by raising that price. 107 All the firms would like the industry price to rise to some extent, but the high-price point that a firm would select-the highest the firm would want the uniform price to go before it would do better by cheating rather than going along with its rivals-would differ from firm to firm. A firm with a small market share and a greater ability to expand output inexpensively might prefer to cheat rather than accept the higher industry price that a firm with a high share and a high cost of expanding output would prefer the industry to adopt.

In equilibrium, the coordinated price would be the lowest of those highprice points: the lowest price that any individual firm would accept if it knew that its rivals would charge the identical price. The constraint on coordination would be the incentive of the firm M (for "maverick") that prefers the lowest coordinated industry price not to raise the industry price further. If following a merger between firm $\mathrm{M}$ and a rival the merged firm prefers a higher price than did pre-merger firm $\mathrm{M}$, that will relax the constraint on coordination previously imposed by firm $\mathrm{M}$, leading prices to rise.

In consequence, courts and enforcers should be concerned particularly about the coordination-enhancing potential of mergers that involve a maverick in an industry where coordination through purposive conduct is

106 More technically, we are working within the economic framework of oligopoly repeated games as it is usually interpreted in antitrust economics, although in pure game theory there is no assumption that players seek any particular outcome.

107 This simplifying assumption, made for expositional convenience, rules out the possibility that the firms would, for example, choose different prices for different firms, or pay high cost firms to reduce output more than low cost firms. Nothing of consequence in the example would change if prices differed across firms, perhaps reflecting differences in product quality, and the firms preserved those price differences when increasing their prices. 
ongoing or appears feasible. ${ }^{108}$ Although the term "maverick" has been used loosely, confusing the district court in $H \xi^{3} R$ Block, ${ }^{109}$ we refer to a setting in which firms would cheat by cutting its price to below the coordinated price. In this setting, a maverick is a firm that is most apt to be the binding constraint on coordination, as by being nearly indifferent between going along with a high coordinated price and cheating on that price. 110 In the above example, the maverick is the firm that prefers the lowest coordinated price and will keep the coordinated price from increasing further simply by refusing to go along. As the example suggests, a merger involving a maverick may relax the maverick's constraint on the effectiveness of industry coordination, leading to higher prices.

A maverick, according to our definition, can be identified in a number of ways. ${ }^{111}$ For example, a firm is likely to be considered a maverick if it has actually declined to go along with recent attempts by others to raise the coordinated price.112 If other firms foresee such behavior, they may avoid attempts to raise the price. ${ }^{113} \mathrm{~A}$ maverick may be identified by structural features that make it less willing than its rivals to go along with more ambitious coordination, such as a small share and substantial ability to expand output inexpensively.114 A maverick could also be identified when industry prices respond to factors that affect its own marginal costs but not the costs

108 See generally, Jonathan B. Baker, Mavericks, Mergers, and Exclusion: Proving Coordinated Competitive Effects Under the Antitrust Laws, 77 N.Y.U. L. REV. 135 (2002) (explaining how coordinated competitive effects analysis can be reconstructed around the role of a maverick firm that constrains prices when industry coordination is incomplete). For enforcement examples see, e.g., Complaint, United States v. Anheuser-Busch InBEV SA/NV (D.D.C. 2013) (No. 13-00127); FCC Staff Analysis and Findings, In re Applications of AT\&T, Inc. \& Deutsche Telekom AG, WT Docket No. 11-65 (Nov. 29, 2011).

109 HER Block, 833 F. Supp. 2d at 79-80. The court rejected the term as confusing but nevertheless found anticompetitive coordinated effects on the ground that the merger involved the acquisition of a firm that played the role of a maverick by our definition. Id.

110 It is also possible that firms would deviate by declining to punish cheating rivals (cheating on the "punishment state"). Then a maverick would be nearly indifferent to participating in the punishment of cheaters.

111 Others employ the term maverick more broadly to also include a firm that competes more aggressively than its rivals, including when oligopolists are not coordinating through repeated interaction. See, e.g., John E. Kwoka, Jr., The Private Profitability of Horizontal Mergers with NonCournot and Maverick Behavior, 7 INT'L J. INDUS. ORG. 403, 410 (1989) (describing maverick firms as those firms with "a particularly small conjectural variation, causing output expansiveness in its industry" or a firm "whose demise results in an increase in the remaining firms' conjectural variations") (emphasis omitted).

112 See Baker, supra note 108, at 174 (describing behaviors associated with maverick firms).

$113 \mathrm{Id}$.

114 Id. at $175-76$. 
of its rivals. 115 Different firms can be mavericks at different times or on different competitive dimensions.116

The potential for a merger involving a maverick to enhance oligopoly coordination links growing concentration from the reduction in the number of significant rivals with competitive harm. The odds that a randomly selected merger among market participants involves a maverick increase as the number of significant rivals falls-and even that calculation would understate the likelihood given the incentive of firms to make acquisitions that facilitate coordination. ${ }^{117}$ This link supports a structural presumption of coordinated harm from horizontal mergers when strategic conduct is purposive. ${ }^{118}$

\section{B. Coordinated Effects Involving Nonpurposive Strategic Conduct}

A merger could also create coordinated effects, and therefore harm competition, by affecting nonpurposive strategic conduct. If, as a result of a merger, oligopolists engaging in nonpurposive strategic conduct change their expectations of the way their rivals will naturally or predictably respond in the competitive and market environment, the coordinated outcome can change. Coordinated effects arise when the new coordinated outcome is worse for buyers.

In order to explain how a merger can create coordinated effects when strategic conduct is nonpurposive, we distinguish two ways that rivals may naturally respond, which we term reinforcing and diluting. We say that rivals' reactions in the industry are "reinforcing" when they go in the same direction (e.g., rivals' reactions to a price cut generally involve price cuts) and "diluting" when they go in opposite directions (e.g., rivals' reactions to a

$115 \mathrm{Id}$. at 174-75 (describing how the market price will change if a maverick firm's marginal costs rise or fall).

116 When challenging the US Airways/American merger, the government alleged that the merger would enhance coordination on two different dimensions: with US Airways a maverick on one dimension (involving discounted connecting fares) and American a maverick on the other (involving aggregate capacity). See Amended Complaint at 17-19, 26, United States v. U.S. Airways Grp., Inc. (D.D.C. 2014) (No. 1:13-01236) (describing US Airways as offering connecting service at a substantial discount to the nonstop service of other airlines on the same routes, while other airlines generally do not undercut the nonstop fares of their rivals, and describing American's standalone expansion plan as undermining the industry's capacity discipline).

117 See Baker, supra note 108, at 198 ("[T] he fewer the number of significant sellers, the more likely it is that the loss of any one would be the loss of a firm that constrains coordinated conduct.").

118 While we have emphasized the way increased concentration or the loss of a maverick from merger enhance the prospects for purposive coordination, they are not the only way mergers can make purposive coordination more likely or more effective. Mergers may also do so by making it easier to identify terms of coordination or increasing the speed or extent of punishments for cheating, for example by increasing the transparency of prices or increasing symmetry among firms. See supra notes 35 and 88 and accompanying text. Factors such as these may facilitate the exercise of purposive coordination even when firms were coordinating nonpurposively before the merger. See supra note 104 . 
capacity increase generally involve capacity reductions). ${ }^{119}$ As our hypothetical examples will demonstrate, a merger will create an adverse coordinated effect when strategic conduct is nonpurposive and the merger would be expected to strengthen reinforcing reactions or weaken diluting reactions. The examples suggest market features that courts and enforcers could look for to identify mergers with coordination-enhancing potential. But the analysis of coordinated effects of mergers involving nonpurposive strategic conduct is in its infancy, and we expect that more such possibilities will become evident over time.

\section{Reinforcing Reactions}

When the relevant reactions are reinforcing, competitive harm would be expected if the merger strengthens those reactions by making them sharper, more prompt, or more likely. Suppose that price reactions are reinforcing: a firm contemplating a price cut expects its rivals to cut their prices in response and a firm contemplating a price increase expects its rivals to respond by raising their prices. It is plausible that the expectation of reinforcing reactions will discourage the firm from reducing prices and encourage it to increase prices. A merger that makes those reactions stronger or more certain will tend to harm buyers. As such, a merger will more strongly discourage price reductions and more strongly encourage price increases.

We think it is often plausible that a horizontal merger will strengthen reinforcing nonpurposive reactions. The merged firm is necessarily a larger part of its rivals' competitive environment than were the merging parties before the merger. In an industry with four comparably significant firms, for example, any one firm might cut its price with the expectation that, for each of the other three, the competitive environment would remain predominantly as it was before the price cut, limiting those rivals' natural and predictable reinforcing responses. That expectation could change with a merger, strengthening their responses and thereby leading to a higher coordinated price.

To illustrate the way reinforcing reactions can strengthen as the number of firms shrink, suppose that in this industry, firms respond to price changes by rivals with a lag, and that when a responding firm adjusts its price, it matches an average of all other firms' prices. ${ }^{120}$ Then, in a four-firm industry, if one firm lowers its price, it will take several time lags before the other firms'

119 In the discussion here, we assume (as is the case when prices or capacities are decision variables) that an increase by one firm either benefits consumers and harms rivals or vice versa. If we allowed for a decision variable that has same-sign effects on consumers and rivals, our discussion would become more cumbersome.

120 See Brown \& MacKay, supra note 62, at $1 \mathrm{n} .3$ (indicating that in practice, pricing algorithms typically adjust prices based on the average price of a set of competitors). 
prices come into near parity with the first mover's. Meanwhile, the price cutter will be attracting more customers, who may remain its customers when price parity is (approximately) restored. Under such circumstances, the first firm's price reduction could be profitable. By contrast, if the industry shrinks to two firms, and the duopolists employ the same behavioral rule, a price cut by one firm would promptly lead its rival to match in full, likely making pricecutting unprofitable.

The basic insight from the example does not rely on its specific behavioral pattern. The example shows, based on intuitively plausible mechanics, that a firm in an industry with a somewhat competitive market structure may expect its price movements to be only partially matched or matched only with a lag, while a firm in a more concentrated industry may expect such matching to be prompter and fuller. The faster and stronger reactions in the more concentrated industry would be expected to discourage price-cutting and encourage price increases. ${ }^{121}$

This example illustrates how a merger that increases concentration significantly when reactions are reinforcing can lead sellers to hold back from procompetitive actions for nonpurposive strategic reasons-more precisely, to hold back more than they did before-thereby harming buyers. As the 2010 Merger Guidelines state,

A market typically is more vulnerable to coordinated conduct if a firm's prospective competitive reward from attracting customers away from its rivals will be significantly diminished by likely responses of those rivals. This is more likely to be the case, the stronger and faster are the responses the firm anticipates from its rivals. The firm is more likely to anticipate strong responses if there are few significant competitors .... 122

The insight from the example links expected responses to the level of market concentration. It thus supports a structural presumption of harm from horizontal merger when strategic conduct is nonpurposive and reactions are reinforcing.

\section{Diluting Reactions}

In other industries-for example, ones in which firms compete primarily by setting output levels or choosing capacities - it may be reasonable to expect diluting reactions, not reinforcing ones. ${ }^{123}$ Firms contemplating reducing

121 If responses are also more certain in the more concentrated industry, that feature, too, would be expected to discourage price-cutting and encourage price increases.

1222010 HMG, supra note 13 , at 26.

123 When the reactions in question tend to dilute the initial competitive impact of a change, those reactions will often make the industry more competitive than a static Nash analysis would predict. A 
output or capacity may be more likely to expect rivals to expand output or capacity in response rather than to pull back, and firms increasing capacity may be more likely to expect rivals to postpone their own capacity increases.

In such an industry, harm may arise if a merger weakens the firms' diluting responses. This might happen for at least two reasons. First, the merged firm faces fewer rivals, with less total capacity, than did either pre-merger partner. Therefore, when deciding whether to cut back its output, the firm may expect a more muted output expansion by rivals than before. Second, ordinary unilateral effects will often reduce the merged firm's profit-maximizing output. If that shift also reduces the firm's profit-maximizing change in output in response to a nonmerging firm's output reduction (relative to the aggregate response of the merging firms prior to the merger), the nonmerging firms will anticipate a weaker diluting response to their own output changes and will thus be encouraged to reduce their output.

For example, consider a merger in an industry with a relatively homogenous product, where the firms have fixed capacities and rising marginal costs of production. The merger of two fairly large rivals would be expected to create a firm that has a unilateral incentive to reduce output in order to increase the industry price. One reason is that the merged firm would have a greater base of sales on which to profit from a higher industry price. A second reason is that the merged firm would recognize that less industry capacity is in the hands of other firms. The acquired firm's capacity would no longer be used to expand output in response to an output reduction by the merged firm. Thus, the merged firm would expect the magnitude of the aggregate supply response it would face if it were to raise prices would be reduced (relative to the supply response the merger partners previously faced). Moreover, that reaction is natural and predictable, so nonmerging rivals would understand that the merged firm's incentives have changed. Each nonmerging firm would assume that the merged firm would not expand output much, if at all, in the event the nonmerging firm reduces output, giving each an incentive to raise price. ${ }^{124}$ The upshot is that after the merger, all firms would have a greater incentive than before to reduce output and increase prices, making competitive harm from merger likely. ${ }^{125}$

merger that weakens such reactions will harm competition even if the post-merger industry remains more competitive than a static Nash analysis (given the post-merger market structure) suggests.

124 In terms of the decomposition proposed by Landes and Posner, the merger in the above example increases the merged firm's market power by reducing the elasticity of nonmerging rival supply. William M. Landes \& Richard A. Posner, Market Power in Antitrust Cases, 94 HARV. L. REV. 937, 945 (1981) (explaining that the higher the elasticity of rival supply, the less a firm's market power).

125 See, e.g., Competitive Impact Statement at 1, 9-10, United States v. Int'l Paper Co., No. 1:12-cv-00227 (D.D.C. 2012), http://www.justice.gov/atr/cases/f280100/280135.pdf [https:// perma.cc/9J9J-3 $\left.\mathrm{V}_{5} \mathrm{~L}\right]$ (arguing that the merger would result in a loss of competition and thus result 
The example illustrates how a horizontal merger that increases concentration substantially when reactions are diluting can weaken those reactions and thus make firms more willing to accommodate price increases. Under such circumstances, the firms would be expected to increase prices. The example also links a weakening of expected supply responses, and greater risk of competitive harm, to an increased level of market concentrationthereby supporting a structural presumption of harm from horizontal mergers when strategic conduct is nonpurposive and reactions are diluting.

\section{Concluding Comments on the Coordinated Effects of Mergers}

Just as a horizontal merger could simultaneously create unilateral and coordinated competitive effects, ${ }^{126}$ a horizontal merger could simultaneously create coordinated competitive effects through its effect on both purposive and nonpurposive conduct. In addition to the familiar effects on purposive coordination, industry firms could be led to act less aggressively by strengthening reinforcing nonpurposive reactions or weakening diluting nonpurposive reactions. In other cases, though, one coordination theory will be more plausible than the other or a merger may have opposing effects on the prospects for coordination through the two types of conduct. ${ }^{127}$

Our analysis of mergers shows that regardless of whether coordinated outcomes arise from purposive or nonpurposive strategic conduct, coordination will often become more likely or more effective as the number of firms in an industry shrinks. A merger is more likely to involve a maverick, and thereby enhance coordination, as the number of significant rivals falls. ${ }^{128}$ Similarly, as concentration grows, firms will react differently to a larger merged firm's strategic moves than they previously did to smaller rivals' moves-potentially enhancing coordination by strengthening reinforcing nonpurposive strategic conduct and weakening diluting nonpurposive strategic conduct. ${ }^{129}$ Accordingly, a structural presumption makes sense with respect to both ways of thinking about strategic conduct and coordinated outcomes.

in higher prices and lower output in the United States by leading the merged firm to reduce output strategically and leading nonmerging rivals to respond by increasing prices).

126 E.g., Miller, Sheu \& Weinberg, supra note 5, at 29 (identifying both unilateral and coordinated competitive effects of a horizontal merger through a simulation model).

127 For example, if a merger leads to less competitive reactions, thus enhancing nonpurposive coordination, and if the most plausible punishment strategies for purposive coordination involve reversion to the one-shot interaction, the merger could simultaneously reduce the prospects for purposive coordination by making punishment less severe. To similar effect, if the merger makes prices more transparent, the merger can facilitate purposive coordination, see supra note 118 , and it may strengthen reinforcing nonpurposive conduct.

128 See supra note 106 and accompanying text.

129 See supra Section III.B. 
In our view, the plausibility of persistent coordinated conduct in oligopoly markets combined with the limitations in the precision of our predictive tools strengthens the case for a structural merger policy, by which coordinated effects are presumed when a horizontal merger increases concentration significantly in a concentrated market. Since the structural presumption was introduced in the 1960s, ${ }^{130}$ its strength has eroded, in part due to Chicago school skepticism about the likelihood and sustainability of oligopolistic coordination. ${ }^{131}$ As courts come to recognize that coordination is a substantially greater concern in modern economics than it appeared to Chicago-oriented commentators and courts, they can be expected to strengthen the presumption by requiring stronger rebuttal evidence for any given concentration level and increase. 132

\section{CONCLUSION}

Coordinated oligopoly outcomes arise when firm conduct is substantially influenced by the prospect of rivals' reactions. Reactions can be purposive, designed to punish cheating from consensus terms of coordination, but they need not be. They can also be nonpurposive: natural and predictable responses to the change in a firm's competitive environment when one of its rivals makes a competitive move such as a price change. We do not suppose that either purposive or nonpurposive coordination is inevitable in oligopoly markets, nor that it invariably raises price substantially above the nonstrategic benchmark. But, as we have demonstrated, coordinated oligopoly outcomes are common and harmful.

While we have stressed the broad scope of strategic conduct and coordinated outcomes, we have also explained that even narrowly defined "coordination" is not as difficult and unlikely as Chicago-oriented courts and commentators suppose. Criminal convictions for illegal collusion are surely the tip of that iceberg, and are themselves not rare.

130 United States v. Phila. Nat'l Bank, 374 U.S. 321,363 (1963) (indicating that a merger which produces a firm controlling a high market share and results in a significant increase in market concentration is so inherently likely to lessen competition substantially that it must be enjoined absent evidence clearly showing otherwise).

131 Baker, supra note 7, at 77-80. The nadir was the influential Baker Hughes decision of the D.C. Circuit, handed down in 1990, which described concentration as simply "a convenient starting point" for a "totality-of-the-circumstances" analysis, United States v. Baker Hughes Inc., 908 F.2d 981, 984 (D.C. Cir. 1990), and explicitly disclaimed a requirement that defendants make a "clear showing" to rebut the inference of competitive harm. Id. at 992.

132 For a complementary analysis and a discussion of legislative options for strengthening the structural presumption, see Herbert Hovenkamp \& Carl Shapiro, Horizontal Mergers, Market Structure, and Burdens of Proof, 127 YALE L.J. 1996 (2018). See also Baker, supra note 7, at 77-79 (justifying the structural presumption based on an error-cost analysis). 
In short, coordination is a serious concern in oligopoly, underrated by the Chicagoans and those influenced by their skepticism. Particularly when Sherman Act enforcement against coordination would be weak or inappropriate, but not only then, merger policy should be alert to the risks of coordinated effects, broadly construed, and rely on a strengthened structural presumption in horizontal merger analysis to help control those risks. 